\title{
Intravenous aminophylline in patients already taking oral theophylline: effect on calculated dose of knowledge of serum theophylline concentration on admission
}

\author{
J WIGGINS, OA ARBAB, D E STABLEFORTH, JON G AYRES \\ From the Department of Respiratory Medicine, East Birmingham Hospital, Birmingham
}

ABSTRACT Measurement of serum theophylline concentration is usually recommended before intravenous aminophylline is given to patients taking oral theophylline. Fifty patients with worsening airflow obstruction, all of whom were taking oral theophyllines and who had no contraindication to the use of parenteral aminophylline, were randomly allocated into two groups before treatment was given. The dose of aminophylline was calculated without (group A) and with (group B) knowledge of admission serum theophylline concentration. In group A a regimen incorporating corrections to account for factors affecting theophylline clearance was used in an attempt to represent a "knowledgeable" approach; in group B a formula incorporating the known serum theophylline concentration at the time of admission was used. All loading doses were given over 30 minutes as "mini infusions." The two groups were well matched for age, blood gas tensions, and severity of airflow obstruction. The results for four patients (one from group A and three from group B) were excluded from analysis after completion of the study. In each group the mean admission serum theophylline concentration measured (group A: 8.4 (SD 6.0) mg/l; group B: $7 \cdot 2(5 \cdot 7) \mathrm{mg} / \mathrm{l})$ and the aminophylline doses used (group A: loading bolus $172(45 \cdot 5) \mathrm{mg}$, infusion 815 (198) mg; group B: loading bolus 233 (189) $\mathrm{mg}$, infusion $788(214) \mathrm{mg}$ ) were similar. Mean serum theophylline concentrations during 24 hours' aminophylline treatment, number of patients with a serum theophylline concentration greater than $20 \mathrm{mg} / \mathrm{l}$, symptoms of toxicity, and outcome were also similar in the two groups. Although satisfactory use of parenteral aminophylline was achieved for most patients without knowledge of serum theophylline concentration at the time of admission to hospital (with the aid of a "knowledgeable" clinical approach and constant infusion pumps), prompt measurement of serum theophylline concentration at the time of admission identified patients with either suboptimal or potentially hazardous theophylline concentrations.

Oral theophylline preparations are useful in asthma for long term symptom control, ${ }^{12}$ and their use may be increasing. ${ }^{3}$ Parenteral aminophylline may be used in the treatment of acute asthma ${ }^{4}$ and also in the management of patients where the degree of reversibility is not fully established, though the use of theophyllines in the management of airflow obstruction due to chronic bronchitis and emphysema is controversial. $^{5}$

Many patients admitted to hospital with worsening

Address for reprint requests: Dr J Wiggins, East Birmingham Hospital, Birmingham B9 5ST.

Accepted 15 April 1986 airflow obstruction are taking oral theophyllines and estimates of appropriate intravenous aminophylline dosage in such cases have been found to be imprecise. ${ }^{67}$ It is therefore recommended that serum theophylline concentrations should be measured before and during the use of parenteral aminophylline. ${ }^{8-10}$ Facilities for measurements are not, however, always available and, even when they are, doctors may wish to start treatment immediately, resorting to "blind" treatment with a low loading dose of aminophylline (for example, $2 \cdot 5-3 \cdot 0 \mathrm{mg} / \mathrm{kg}) .{ }^{41112}$

In a recent study of the use of parenteral aminophylline in a district general hospital ${ }^{7}$ we found that 
clinicians vary in their practice and were often unaware of interpatient variability and other factors affecting theophylline clearance. We recommended regular monitoring of concentrations, and a more "knowledgeable" clinical approach to the use of intravenous aminophylline in patients taking oral theophyllines.

The purpose of this prospective study was to determine the value of prompt measurement of the serum theophylline concentrations of patients receiving oral theophylline on their admission to hospital with worsening airflow obstruction. Two schemes for parenteral aminophylline dosage were compared: in one the doses were calculated from a formula with knowledge of serum theophylline concentration at admission; in the other scheme, representing a "knowledgeable" clinical approach, doses were based on a standard regimen that was adjusted to account for factors known to affect theophylline clearance.

\section{Methods}

\section{PATIENTS}

Fifty adult patients ( 23 of them women), mean age $59.3(14.7)$ years, who had been prescribed (and informed us that they were taking) regular slow release theophylline drugs prior to admission, were entered into the study. Patients known to have liver disease or allergy to theophyllines, and those receiving drugs known to affect theophylline clearance, were excluded. All patients gave informed consent and the study was approved by the hospital ethical committee.

Patients were recruited on arrival in the accident and emergency department and entered into the study at the discretion of the admitting doctor, usually a senior house officer with experience in respiratory medicine under supervision of a more experienced clinician. Indications for the use of parenteral amino-

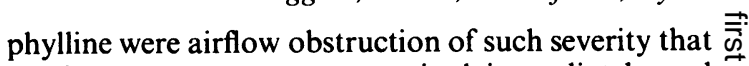
maximum treatment was required immediately and $\overrightarrow{0}$ failure to respond satisfactorily (less than $20 \%$ 등 increase in peak flow after 20 minutes) to initial $\frac{\bar{s}}{\square}$ bronchodilator treatment (nebulised salbutamol $\stackrel{\varnothing}{\propto}$ $5 \mathrm{mg}$, with or without ipratropium bromide $0.25 \mathrm{mg}$ ).

The patients were studied for the first 24 hours of ${ }^{\infty}$ parenteral aminophylline treatment, during which $\vec{\rightarrow}$ time all received intravenous hydrocortisone and neb- $\overrightarrow{\vec{\omega}}$ ulised bronchodilators in conventional doses. In $\stackrel{\omega}{\omega}$ group $\mathrm{A}$ the aminophylline doses to be given were $\vec{x}$ predicted without knowledge of serum theophylline concentration on admission. In group B doses were $\overrightarrow{-}$ determined with this knowledge. Doses were calcu- $\vec{\circ}$ lated on the basis of the patient's ideal body weight of except where the actual body weight was less than ideal.

\section{LOADING DOSES}

The desired dose of aminophylline was made up to $60 \mathrm{ml}$ with normal saline and given as a "miniథ infusion" over half an hour with a constant infusion $\vec{\oplus}$ pump, in both groups.

Group $A$ The basic loading dose was $2.5 \mathrm{mg} / \mathrm{kg}$ for non-smoking patients taking oral theophylline; ${ }^{4}$ this was adjusted to account for factors known to alter theophylline clearance. ${ }^{10}$ In smokers the dose was multiplied by 1.5 , in patients with cardiac failure by 0.4 , and in patients with pneumonia by 0.4 and by 0.8 if the arterial oxygen tension $\left(\mathrm{PaO}_{2}\right)$ was less than $\overrightarrow{\mathrm{O}}$ $8 \mathrm{kPa}$. The correction factors were multiplied if condi- 3 tions coexisted. The actual doses given were adjusted to the nearest $25 \mathrm{mg}$ (see table 1).

Group $B$ These patients were only given loading doses if the serum theophylline on admission was less than $10 \mathrm{mg} / \mathrm{l}$. Doses were calculated using the following formula ${ }^{4}$ :

Loading dose $=$ (desired conc. - measured conc. $) \times$ $1.25 \times \mathrm{VD}$

Table 1 Theophylline loading doses given to patients in group $A^{*}$

\begin{tabular}{|c|c|c|c|c|c|c|c|c|}
\hline & \multicolumn{4}{|c|}{ Non-smoker } & \multicolumn{4}{|l|}{ Smoker } \\
\hline & $\begin{array}{l}\text { No } C F \\
\text { No } H\end{array}$ & $\underset{H}{N o} C F$ & $\begin{array}{l}\text { CF } \\
\text { No } H\end{array}$ & $\begin{array}{l}\underset{H}{C F} \\
\end{array}$ & $\begin{array}{l}\text { No } C F \\
\text { No } H\end{array}$ & $\underset{H}{N o} C F$ & $\begin{array}{l}\text { CF } \\
\text { No } H\end{array}$ & $\stackrel{\underset{H}{C F}}{ }$ \\
\hline Basic dose $\mathrm{mg} / \mathrm{kg}$ & 2.5 & $2 \cdot 0$ & $1 \cdot 0$ & 0.8 & 3.75 & 3.00 & $1 \cdot 5$ & $1 \cdot 2$ \\
\hline $\begin{array}{l}\text { Ideal body Wt (kg) } \\
50 \\
60 \\
70 \\
80 \\
90 \\
100\end{array}$ & $\begin{array}{l}125 \\
150 \\
175 \\
200 \\
200 \\
250\end{array}$ & $\begin{array}{l}100^{\circ} \\
125 \\
150 \\
150 \\
175 \\
200\end{array}$ & $\begin{array}{r}50 \\
50 \\
75 \\
75 \\
100 \\
100\end{array}$ & $\begin{array}{l}50 \\
50 \\
50 \\
50 \\
75 \\
75\end{array}$ & $\begin{array}{l}200 \\
225 \\
250 \\
300 \\
325 \\
375\end{array}$ & $\begin{array}{l}150 \\
150 \\
200 \\
225 \\
250 \\
250\end{array}$ & $\begin{array}{r}75 \\
100 \\
100 \\
100 \\
125 \\
150\end{array}$ & $\begin{array}{r}50 \\
50 \\
75 \\
100 \\
100 \\
125\end{array}$ \\
\hline
\end{tabular}

*Results are in $\mathrm{mg}$ and the dose was adjusted to the nearest $25 \mathrm{mg}$ multiple for ease of administration. $\mathrm{CF}$ - cardiac failure; $\mathrm{H}-$ hypoxaemid $\left(\mathrm{PaO}_{2}<8.0 \mathrm{kPa}(60 \mathrm{~mm} \mathrm{Hg})\right)$. Also shown are the basic doses in $\mathrm{mg} / \mathrm{kg}$ ideal body weight. 
1.25 allows correction for the use of aminophylline rather than theophylline as equivalent doses of the drugs are 10:8. The desired theophylline concentration chosen was $15 \mathrm{mg} / \mathrm{l}$. The volume of distribution (VD), the fluid volume that would contain a known dose of drug if the measured plasma concentration were uniform throughout the body water, was taken as $0.51 / \mathrm{kg}$; for example, for a $70 \mathrm{~kg}$ man a figure of 35 is entered into the equation.

\section{INFUSIONS}

Non-smoking patients were given infusions with a constant infusion pump at a rate of $0.5 \mathrm{mg} / \mathrm{kg}$ an hour. In smokers the infusion rates were adjusted with the correction factor of $1 \cdot 5$.

\section{SERUM THEOPHYLLINE CONCENTRATION}

Venous blood was promptly taken for estimation of theophylline concentration when patients were admitted to the accident and emergency department. Further samples were taken during parenteral aminophylline treatment after half an hour and one, three, five, seven, 12, and 24 hours where possible. Estimations of serum theophylline concentrations were made in the adjacent biochemistry laboratory (a few minutes' walk from the accident and emergency department) by an enzyme mediated immunoassay technique (EMIT system; Zyva Corporation, USA). Results for patients in group B were generally available 20 minutes after the blood sample was taken; blood samples from patients in group A were assayed during normal working hours, generally the day after admission.

\section{OTHER MEASUREMENTS}

Peak expiratory flow (PEF) was measured at the time each blood sample was taken. Serum electrolytes and arterial blood gases were measured and liver function tests were performed, and an electrocardiogram and a chest radiograph were obtained before parenteral aminophylline treatment was started. Where possible, continuous (Holter) electrocardiographic recordings were started while the patient was still in the accident and emergency department and continued throughout the period of the intravenous infusion.

Symptoms of theophylline intolerance (nausea and , vomiting, headache, and heartburn) were assessed with a $10 \mathrm{~cm}$ visual analogue scale for all patients on their arrival in the accident and emergency department and at the time of the half and one hour blood samples. At the times of subsequent blood sampling patients with symptoms filled in further visual analogue scales; symptomless patients were assumed to have scores of zero.

Differences between the two groups were assessed statistically with the Wilcoxon rank sum test for unpaired data and analysis of variance.

\section{Results}

Of the 50 patients studied, four were excluded from consideration in the results. One patient was withdrawn from group A because treatment with erythromycin was started during the aminophylline infusion. Three were withdrawn from group $\mathbf{B}$, two because oral theophylline was inadvertently continued during the aminophylline infusion and a third because wheezing was found to be due to a bronchial carcinoma.

All patients in group A, 13 of whom were smokers, had asthma. Eight patients (all men) in group B, three of whom were smokers, had worsening airflow obstructon related to chronic bronchitis and emphysema. The remainder in group B (14 patients, 9 of them smokers) had asthma.

There was no significant difference between the two groups with respect to either age, body weight (actual or ideal), or arterial blood gas tensions (table 2).

\section{SERUM THEOPHYLLINE CONCENTRATIONS ON ADMISSION}

Both groups had a wide range of serum theophylline

Table 2 Age, body weight, and arterial blood gas tensions of patients admitted to the study (means with standard deviations and ranges in parentheses)

\begin{tabular}{lll}
\hline & Group $A(n=24)$ & Group B $(n=22)$ \\
\hline Age (y) & & \\
All & $60 \cdot 2(15 \cdot 6)(25-82)$ & $58 \cdot 5(13 \cdot 4)(20-76)$ \\
Men & $66 \cdot 5(11.9)(43-82)$ & $60 \cdot 0(11 \cdot 8)(33-72)$ \\
Women & $54 \cdot 8(16 \cdot 4)(25-78)$ & $55 \cdot 8(15 \cdot 5)(20-76)$ \\
Body weight (kg) & $67 \cdot 4(16 \cdot 8)(46-114)$ & $67 \cdot 0(16 \cdot 9)(41-98)$ \\
$\quad$ Actual & $59 \cdot 3(9 \cdot 2)(45-73)$ & $62 \cdot 6(6 \cdot 5)(50-72)$ \\
Ideal & $9 \cdot 3(2 \cdot 7)(5 \cdot 3-15 \cdot 6)$ & $9 \cdot 2(2 \cdot 7)(5 \cdot 2-14 \cdot 2)$ \\
Blood gases $(\mathrm{kPa})$ on admission & $5 \cdot 1(1 \cdot 0)(3 \cdot 4-8 \cdot 0)$ & $5 \cdot 4(1 \cdot 2)(3 \cdot 7-7 \cdot 7)$ \\
$\mathrm{PaO}_{2}$ &
\end{tabular}

$\mathrm{PaO}_{2}$-arterial oxygen tension: $\mathrm{PaCO}_{2}$-arterial carbon dioxide tension.

Conversion: SI to traditional units-Blood gas tensions: $1 \mathrm{kPa} \approx 7.5 \mathrm{~mm} \mathrm{Hg}$. 
concentrations on admission to hospital and the mean values were similar (table 3). There was no significant difference between the groups in the number of patients with a serum theophylline concentration on admission less than $5 \mathrm{mg} / \mathrm{l}$ or greater than $20 \mathrm{mg} / \mathrm{l}$.

\section{DOSE OF AMINOPHYLLINE}

There was no significant difference between the bolus doses given to the two groups. The mean (SD) values in $\mathrm{mg}$ and the ranges were as follows: group A 172 (45) (125-300); group B 233 (189) (0-575). There was also no significant difference in the mean total infused dose between the two groups (mean (SD) values $(\mathrm{mg} / 24 \mathrm{~h})$ and ranges: group A 815 (197) (550-1450); group B 788 (213) (450-1300).

\section{SERUM THEOPHYLLINE CONCENTRATIONS}

DURING INFUSIONS

Complete series of serum theophylline concentrations were available from all patients during aminophylline treatment except for two (group A) at one hour, two (group B) at five hours, and one (group B) at seven hours. Average serum theophylline concentrations during aminophylline infusions were similar in the two groups (table 3), although results in group A tended to be more variable (fig 1). There was no difference in the numbers of patients with a theophylline concentration of less than $5 \mathrm{mg} / \mathrm{l}$, from 20 to $25 \mathrm{mg} / \mathrm{l}$, and greater than $25 \mathrm{mg} / \mathrm{l}$ in each group at any point during the aminophylline infusions. A comparison of individual admission and one hour serum theophylline concentration is shown in figure 2 .

\section{PEF MEASUREMENTS}

There was no significant difference between the groups with respect to PEF either on admission (mean (SD) values: group A $95(60) 1 \mathrm{~min}^{-1}$, group B $146(93) 1 \mathrm{~min}^{-1}$ or after 24 hours, aminophylline treatment (mean values: group A $234(97) 1 \mathrm{~min}^{-1}$; group B $\left.225(117) 1 \mathrm{~min}^{-1}\right)$.

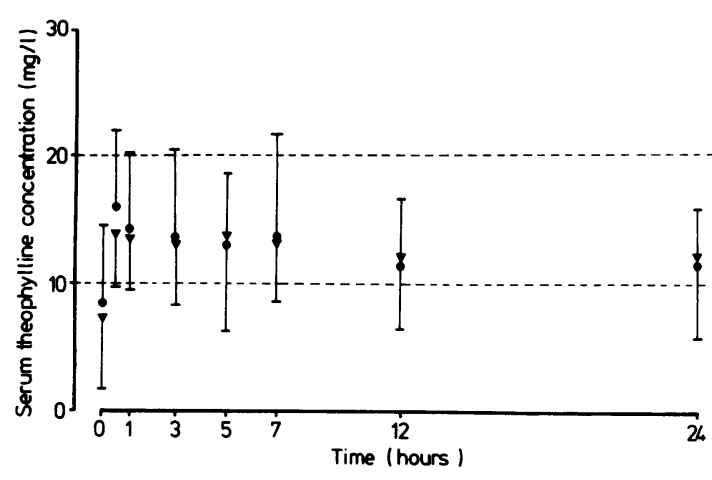

Fig 1 Mean serum theophylline concentrations ( $m g / l)$ during parenteral aminophylline treatment. Dots indicate group $A$ and triangles group $B$; the bars represent one standard deviation. The broken lines indicate the therapeutic range of serum theophylline concentration $(10-20 \mathrm{mg} / \mathrm{l})$.

\section{SYMPTOMS OF THEOPHYLLINE TOXICITY}

Symptoms of theophylline toxicity were minimal in both groups throughout the study and in most patients visual analogue scale scores were zero throughout.

One patient in group A, whose highest theophylline concentration was $19.2 \mathrm{mg} / \mathrm{l}$, vomited during the aminophylline infusion. One patient in group B developed severe nausea without vomiting (highest theophylline concentration $22.6 \mathrm{mg} / \mathrm{l}$ ) during the infusion; this patient's infusion rate had been temporarily increased by mistake. There were no symptoms after bolus doses in any patient and no other symptom of toxicity was detected at any stage during treatment.

No patient suffered a convulsion and no cardiac arrhythmia requiring treatment was detected clinically. Technically satisfactory Holter electrocardiographic recordings were obtained from only 18 patients, 10 in group A and 8 in group B. No major arrhythmia was detected in 12 of the patients. Three other patients showed atrial fibrillation throughout

Table 3 Serum theophylline concentrations* during intravenous theophylline treatment (means with standard deviations and ranges in parentheses)

\begin{tabular}{|c|c|c|}
\hline & Theophylline concentration $(\mathrm{mg} / \mathrm{l})$ & \\
\hline Time (h) after admission & Group $\bar{A}(n=24)$ & Group B $(n=22)$ \\
\hline $\begin{array}{c}0 \\
1 / 2 \\
1 \\
3 \\
5 \\
7 \\
12 \\
24\end{array}$ & $\begin{array}{c}8 \cdot 4(6 \cdot 0)(1-24 \cdot 1) \\
16 \cdot 0(6 \cdot 4)(3 \cdot 5-27 \cdot 1) \\
14 \cdot 0(6 \cdot 9)(5 \cdot 1-32 \cdot 3) \\
13 \cdot 5(6 \cdot 8)(4 \cdot 8-30 \cdot 4) \\
13 \cdot 2(7 \cdot 0)(4 \cdot 3-34 \cdot 8) \\
13 \cdot 3(8 \cdot 3)(4 \cdot 6-27 \cdot 7) \\
11 \cdot 5(5 \cdot 4)(2 \cdot 7-29 \cdot 0) \\
11 \cdot 3(5 \cdot 7)(1-24 \cdot 9)\end{array}$ & $\begin{array}{r}7 \cdot 2(5 \cdot 7)(1-18 \cdot 1) \\
13 \cdot 7(3 \cdot 9)(8 \cdot 1-21 \cdot 5) \\
13 \cdot 4(4 \cdot 1)(6 \cdot 7-21 \cdot 4) \\
13 \cdot 0(4 \cdot 8)(4 \cdot 4-26 \cdot 0) \\
13 \cdot 3(5 \cdot 2)(4 \cdot 3-28 \cdot 0) \\
13 \cdot 1(4 \cdot 6)(4 \cdot 5-25 \cdot 0) \\
11 \cdot 9(4 \cdot 8)(3 \cdot 8-22 \cdot 6) \\
11 \cdot 3(4 \cdot 6)(4 \cdot 7-21 \cdot 0)\end{array}$ \\
\hline
\end{tabular}

*Complete serum theophylline concentrations were available from all patients except for two (group A) at 1 hour, two (group B) at 5 hours, and one (group B) at 7 hours. 


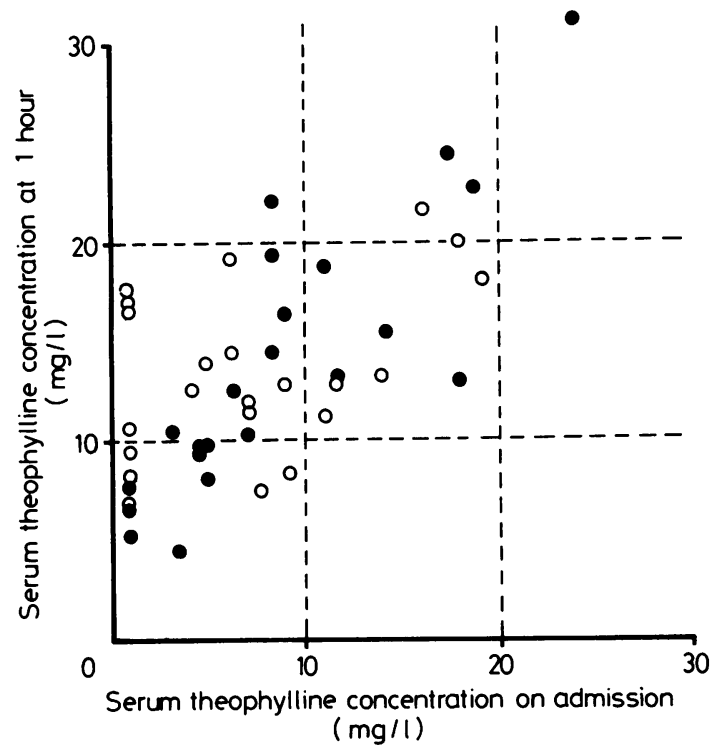

Fig 2 Comparison of serum theophylline concentrations on admission to hospital and one hour after the start of intravenous aminophylline treatment. Closed circles indicate group $A(n=22)$ and the open circles group $B(n=22)$. The broken lines indicate the therapeutic range of serum theophylline concentration $(10-20 \mathrm{mg} / \mathrm{l})$.

the study and each had frequent ventricular ectopic activity. The remaining three patients had bursts of supraventricular tachycardia with frequent atrial and ventricular premature beats. There was no obvious association between serum theophylline concentration and cardiac arrhythmia.

\section{Discussion}

There are potential difficulties in the use of parenteral aminophylline in patients already taking oral theophyllines. It has been recommended on the basis of pharmacokinetic studies ${ }^{8-10}$ that serial measurements of serum theophylline concentration should be made and that subsequent aminophylline doses should be calculated from formulae. Clinical studies have supported these recommendations. ${ }^{713}$ The formulae suggested have wide confidence limits, ${ }^{10}$ however, and the assays are costly. The purpose of this prospective study was to assess the value of knowledge of serum theophylline concentration at the time of admission to hospital by comparison of two aminophylline dosage regimens, one with and the other without availability of this information.

The treatment regimens used in this study were such that aminophylline loading doses were given to all patients who were randomised into group A. It has been suggested that this approach is potentially haz- ardous. ${ }^{6}$ Boluses were given to only seven patients whose admission serum theophylline concentration was greater than $10 \mathrm{mg} / \mathrm{l}$ and a potentially dangerous serum concentration $(32.3 \mathrm{mg} / \mathrm{l}$ at 1 hour: fig 2$)$ was recorded in only one patient; parenteral aminophylline was used at a time when this patient's condition was critical because of pneumonia and severe hypoxaemia; the safe, effective use of parenteral aminophylline in these circumstances is extremely difficult. The highest serum theophylline concentration at one hour in the six other patients was $24.5 \mathrm{mg} / \mathrm{l}$ and no symptom suggesting theophylline toxicity was recorded in any of these patients. In comparison two patients in group $B$, who were not given loading boluses because their serum theophylline concentrations on admission were 16.3 and $18.1 \mathrm{mg} / \mathrm{l}$ respectively, also reached a concentration greater than $20 \mathrm{mg} / \mathrm{l}$ at 1 hour. This reflects either changes in theophylline clearance or perhaps the fact that oral theophylline had been taken shortly before admission, so that the concentration on admission did not represent a steady state result.

The use of a loading bolus without knowledge of serum theophylline concentrations did not cause problems in this study, but the average dose given was only $170 \mathrm{mg}$, less than the $250 \mathrm{mg}$ observed in our previous study ${ }^{7}$ and by others. ${ }^{11}$ The loading doses used were derived from the patient's ideal rather than actual body weight. Actual weight was suggested by $\mathrm{Gal}^{14}$ on the basis of a pharmacokinetic study in normal subjects not taking oral theophyllines. This was clearly inappropriate for our study-for example, a woman with asthma whose actual body weight was $114 \mathrm{~kg}$ and whose serum theophylline concentration on admission was $8.4 \mathrm{mg} / \mathrm{l}$ would have been given over $400 \mathrm{mg}$ of aminophylline if her actual body weight had been used rather than her ideal weight, which resulted in a dose of $200 \mathrm{mg}$; this raised the serum concentration at 1 hour to $14.4 \mathrm{mg} / \mathrm{l}$. A factor contributing to the safety of the bolus doses used in both groups of patients in this study was the mode of administration. The doses were given over half an hour as "mini infusions" by constant infusion pumps. This method was chosen because theophylline has two compartment kinetics, in which the bronchodilating effect correlates with the second (or tissue) compartment rather than the initial "volume of distribution" compartment ${ }^{15}$; thus rapid administration may cause very high theophylline concentrations because a finite time is needed for the drug to be distributed from the central to the tissue compartment. ${ }^{4}$ It is generally recommended that loading aminophylline doses are given over $10-15$ minutes, ${ }^{16}$ but our study suggests that this may be too short a time.

A clear problem with the use of loading boluses calculated without knowledge of serum theophylline 
concentration was the undertreatment of patients whose concentration on admission was low. The study design presupposed that group A patients had appreciable theophylline in their blood at the time of hospital admission and individuals who did not were subsequently undertreated. Nevertheless, all such patients in group $\mathrm{A}$ had a serum concentration greater than $5 \mathrm{mg} / \mathrm{l}$ at one hour, which, although not ideal, is associated with a degree of bronchodilatation. ${ }^{17}$ By comparison, three of seven patients in group B whose serum theophylline concentration on admission was less than $2.5 \mathrm{mg} / \mathrm{l}$ also failed to reach a serum concentration within the therapeutic range at 1 hour; thus, even with knowledge of admission serum theophylline concentration, an ideal loading dose cannot be guaranteed for every patient. The target serum theophylline concentration of $15 \mathrm{mg} / \mathrm{l}$ was chosen because it is in the middle of the therapeutic range and allows a safe margin below the potentially toxic range. Choosing a higher value may have improved the serum theophylline concentration at 1 hour in group B, but in view of interpatient variability in theophylline clearance ${ }^{18}$ this would have been at the expense of risking toxicity in some patients.

The average total infusion doses given to the patients in the two groups were similar to those previously recommended $(180 \mathrm{mg}$ six hourly in an adult weighing $60 \mathrm{~kg})^{19}$ and considerably less than those used when clinicians choose doses by guess work (1175 (SD 268) $\mathrm{mg}$ in 24 hours). ${ }^{7}$ Although individual results were more variable in group $\mathrm{A}$, most patients in the study had serum theophylline concentrations greater than $10 \mathrm{mg} / \mathrm{l}$ throughout their aminophylline infusions. Furthermore, results for individual patients were relatively constant throughout the infusion. This is in contrast with the results of our previous study, ${ }^{7}$ which showed that patients are inadequately treated when the doses of infused aminophylline are guessed. In the present study the patients in both groups whose serum theophylline concentrations were lowest during infusions were those whose serum concentration at 1 hour was suboptimal, emphasising the value of using an accurate loading bolus.

Three patients (all critically ill, two in group A and one in group B) were "overtreated" (serum theophylline concentration greater than $25 \mathrm{mg} / \mathrm{l}$ on at least one occasion) during their aminophylline infusions, indicating that neither the use of correction factors nor the knowledge of admission serum theophylline concentration can fully overcome the fluctuations in theophylline clearance that occur in severely ill patients. ${ }^{10}$ Measurement of serum theophylline concentration is valuable during the course of intravenous aminophylline treatment, however, particularly if treatment is prolonged and there are fluctuations in the patient's condition.

The general lack of symptoms of theophylline toxicity in both groups was unexpected and gratifying. No patient complained of either headache or heartburn during the study and only two patients suffered from nausea and vomiting. The lack of symptoms is probably due to the use of constant rate pumps to administer both loading doses ("mini infusions") and maintenance treatment and to setting the "target" theophylline concentration at $15 \mathrm{mg} / \mathrm{l}$, which meant that the theophylline concentration was maintained within the range $5-20 \mathrm{mg} / 1$ in most patients.

Is it possible, in clinical practice, to obtain better serum theophylline concentrations than those seen in the patients in this study, the circumstances of which may not be typical of practice in some district general hospitals? Results might have been improved if two factors could have been overcome. Firstly, understatement by some patients about their smoking habits may have resulted in administration of suboptimal aminophylline doses. Heavy smokers may need three months of abstinence from cigarettes before their theophylline clearance becomes that of a nonsmoker $^{20}$ and the doses of aminophylline used in such patients should be adjusted appropriately. The second and perhaps most difficult problem to contend with was the relationship between the time when the last oral dose of theophylline had been taken and measurement of serum theophylline concentration. Neither treatment regimen used in this study can take this fully into account. It has been suggested that consistent serum theophylline concentrations can be obtained by using drug doses derived from calculations of clearance rates based on two measurements made during aminophylline infusion. ${ }^{21} 22$ Although these methods are claimed to be simple, they are probably impractical for routine clinical practice.

In conclusion, the results of this study suggest that the doses of intravenous aminophylline used in routine clinical practice may be excessive. Measurement of serum theophylline concentration at the time of admission to hospital identified patients whose compliance with oral theophylline treatment was poor or whose maintenance dose was suboptimal, and avoided the administration of loading doses to patients whose admission serum theophylline concentration was potentially toxic. Similar benefit might be obtained, however, by regular non-urgent outpatient monitoring of serum theophylline concentration and, furthermore, knowledge of serum theophylline concentration at the time of admission to hospital does not guarantee optimal parenteral aminophylline treatment. Many patients may be given satisfactory parenteral aminophylline treatment without knowl- 
edge of their serum theophylline concentration on admission, provided that doses are derived from a regimen incorporating a "knowledgeable" clinical approach. Nevertheless, theophyllines are difficult drugs to use in clinical practice and measurement of serum theophylline concentration when patients are admitted to hospital improves their use.

We would like to thank Napp Laboratories for financial assistance, Dr H Pandov for assistance with serum theophylline measurement, Dr PL Weissberg for analysing 24 hour ECG tapes, and Mrs P Jackson for her secretarial help.

\section{References}

1 Greening AP, Baillie E, Gribbin HR, Pride NB. Sustained release oral aminophylline in patients with airflow obstruction. Thorax 1981;36:303-7.

2 Nassif EG, Weinberger M, Thompson R, Huntley W. The value of maintenance theophylline in steroiddependent asthma. $N$ Engl J Med 1981;304:71-5.

3 Woodcock AA, Johnson MA, Geddes DM. Theophylline prescribing, serum concentrations, and toxicity. Lancet 1983;ii:610-3.

4 Hendeles L, Weinberger M. Theophylline: a state of the art review. Pharmacotherapy 1983;3:2-44.

5 Cochrane GM. Slow release theophyllines and chronic bronchitis. Br Med J 1984;289:1643-4.

6 Stewart MF, Barclay J, Warburton R. Risk of giving intravenous aminophylline to acutely ill patients receiving maintenance treatment with theophylline. $\mathrm{Br}$ Med J 1984;288:450.

7 Arbab OA, Wiggins J, Ayres JG, Stableforth DE. The use of parenteral aminophylline in patients taking slow release theophylline preparations: an observation of clinical practice. Br J Dis Chest 1985;79:161-71.

8 Jenne JW, Wyze E, Rood FS, MacDonald FM. Pharmacokinetics of theophylline: application to adjustment of the clinical dose of aminophylline. Clin Pharmacol Ther 1972;13:349-60.

9 Weinberger MW, Matthay RA, Ginchansky EJ, Chidsey CA, Petty TL. Intravenous aminophylline dosage. Use of serum theophylline measurement for guidance. JAMA 1976;235:2110-3.
10 Powell JR, Vozeh S, Hopewell P, Costello J, Sheiner LB, Riegelman S. Theophylline disposition in acutely ill hospitalised patients. Am Rev Respir Dis 1978;118:229-38.

11 Munro CS, Prowse K. Doses of aminophylline given intravenously in casualty department and resulting serum theophylline concentrations. $\mathrm{Br} \mathrm{Med} J$ 1984;289:354-5.

12 Rivington RN, Stiell IG, Scott S, MacLeod JP. Intravenous aminophylline dosing for patients receiving chronic oral theophylline therapy: a simpler solution. In: Turner-Warwick M, Levy J, eds. New perspectives in theophylline therapy. JR Soc Med Int Cong Symp No 78, Pub Roy Soc Med, London: Royal Society of Medicine, 1984. (International Congresses and Symposi, No 78).

13 Jacobs MH, Senior RM, Kessler G. Clinical experience with theophylline: relationship between dosage, serum concentration, and toxicity. JAMA 1976;235:1983-6.

14 Gal P, Jusko WJ, Yurchak AM, Franklin BA. Theophylline disposition in obesity. Clin Pharmacol Ther 1978;23:438-44.

15 Winter ME. Basic clinical pharmacokinetics. San Francisco: Applied Therapeutics Inc, 1980.

16 Joint Formulary Committee 1984-85. British National Formulary 1985. London: British Medical Association and Pharmaceutical Society of Great Britain, 1985: 111.

17 Mitenko PA, Ogilvie RI. Rational intravenous doses of theophylline. $N$ Engl J Med 1973;289:600-3.

18 Hendeles L, Weinberger M, Bighley L. Disposition of theophylline following a single intravenous aminophylline infusion. Am Rev Respir Dis 1978;118:97-103.

19 Anonymous. Intravenous aminophylline: a cautionary note [editorial]. Lancet 1980;i:746.

20 Hunt SN, Jusko WJ, Yurchak AM. Effect of smoking on theophylline disposition. Clin Pharmacol Ther 1976;19:546-51.

21 Chiou WL, Gadalla MAF, Peng GW. Method for the rapid estimation of the total body clearance and adjustment of dosage regimens in patients during a constant rate intravenous infusion. $J$ Pharmacokinet Biopharmacol 1978;6:135-51.

22 Vozeh S, Kewitz G, Wenk M, Follath F. Rapid prediction of steady-state serum theophylline concentration in patients treated with intravenous aminophylline. Eur J Clin Pharmacol 1980;18:473-7. 